\title{
Thyroid hormone signaling and adult neurogenesis in mammals
}

\section{Sylvie Remaud, Jean-David Gothié, Ghislaine Morvan-Dubois and Barbara A. Demeneix*}

UMR CNRS 7221, Evolution des Régulations Endocriniennes, Département Régulations, Développement et Diversité Moléculaire, Muséum National d'Histoire Naturelle, Paris, France

\section{Edited by:}

Frédéric Flamant, Ecole Normale Supérieure de Lyon, France

Reviewed by:

Caterina Missero, CEINGE

Biotecnologie Avanzate, Italy

Ana Cristina Guadaño-Ferraz, Consejo

Superior de Investigaciones

Cientificas, Spain

*Correspondence:

Barbara A. Demeneix, UMR CNRS

7221, Evolution des Régulations

Endocriniennes, Département

Régulations, Développement et

Diversité Moléculaire, Muséum

National d'Histoire Naturelle, Paris

75231, France

e-mail: bdem@mnhn.fr
The vital roles of thyroid hormone in multiple aspects of perinatal brain development have been known for over a century. In the last decades, the molecular mechanisms underlying effects of thyroid hormone on proliferation, differentiation, migration, synaptogenesis, and myelination in the developing nervous system have been gradually dissected. However, recent data reveal that thyroid signaling influences neuronal development throughout life, from early embryogenesis to the neurogenesis in the adult brain. This review deals with the latter phase and analyses current knowledge on the role of $\mathrm{T}_{3}$, the active form of thyroid hormone, and its receptors in regulating neural stem cell function in the hippocampus and the subventricular zone, the two principal sites harboring neurogenesis in the adult mammalian brain. In particular, we discuss the critical roles of $\mathrm{T}_{3}$ and TR $\alpha 1$ in commitment to a neuronal phenotype, a process that entails the repression of a number of genes notably that encoding the pluripotency factor, Sox2. Furthermore, the question of the relevance of thyroid hormone control of adult neurogenesis is considered in the context of brain aging, cognitive decline, and neurodegenerative disease.

Keywords: thyroid hormones, adult neurogenesis, brain functions, adult neural stem cells, plasticity, physiology

\section{THYROID HORMONES AND ADULT BRAIN FUNCTION}

Thyroid hormones (THs) are vital for brain organization and function throughout life. In the developing mammalian embryo prior to instigation of fetal thyroid function maternal THs are required for optimal neurogenesis $(1,2)$. At all life stages, but particularly during perinatal growth, $\mathrm{T}_{3}$ is implicated in multiple processes including neurogenesis (cell cycle control and exit), synaptogenesis, migration, plasticity, and myelination (3). In adults, thyroid dysfunction correlates with neurological and behavioral disorders. Even if developmental hypothyroidism produces more deleterious, irreversible effects, adult hypothyroidism alters hippocampus function: memory impairment, anxiety, and depression-like symptoms in rodent models and humans $(4,5)$. In adults, the mechanisms underlying these cognitive problems are less well understood than during perinatal development. However, it is established that reduced neurogenesis, especially in the rodent hippocampus, due to either aging or stress, is associated with neurocognitive deficits such as anxiety, depression (6), and with neurodegenerative disease such as Alzheimer's $(7,8)$. In mammals, including humans, the subgranular zone (SGZ) of the hippocampal dentate gyrus and the subventricular zone (SVZ) represent the two main neurogenic niches. These niches produce newborn neurons from neural stem cells (NSC) throughout life and so, contribute to brain plasticity during learning, memory, and recovery from brain damage (9). Many extrinsic and intrinsic signaling factors regulate different stages of adult neurogenesis (10), with TH signaling being well known to control NSC homeostasis [see below and (11-16)]. Understanding the mechanisms underlying $\mathrm{T}_{3}$ regulation of adult neurogenesis is crucial to develop treatments for neurocognitive disorders.
A rich literature links thyroid physiology and neurocognitive dysfunction in humans. Hypothyroidism is associated with mood instability and depression, dementia, memory impairment, and psychomotor problems (17). Most often, mood abnormalities reverse under $\mathrm{T}_{4}$-supplementation, but can persist after long-term hypothyroidism (18). The mechanisms implicated are unknown, although $\mathrm{T}_{3}$ levels affect serotoninergic and catecholaminergic signaling at multiple levels $(19,20)$, systems often targeted by antidepressants. Further, in children and adolescents (21), as well as adults (22), hypothyroidism, and reduced memory function are associated with decreased hippocampal size, suggesting that $\mathrm{TH}$ deficiency causes structural alterations. Thus, it is plausible that neurogenesis in rodents, and depression or other psychiatric diseases associated with hypothyroidism in humans, may be related to reduced hippocampal neurogenesis.

However, the links between cognitive deficits and neurogenesis - "the neurogenic hypothesis of depression" - are still poorly understood. Even if there is evidence for adult neurogenesis in both SVZ (23) and SGZ (24) in humans, the contribution of adult neurogenesis to human brain function, and in particular to behavioral outputs, is still questioned, a point discussed in the next section.

However, there is increasing cellular and molecular understanding of the links between TH signaling and adult neurogenesis in rodents. Adult-onset hypothyroidism reduced the number of newborn neuroblasts in the dentate gyrus (14). Furthermore, in adult hypothyroid animals displaying depressive-like behavior, neurogenesis in the dentate gyrus is reduced and dendritic arborization is impaired. TH supplementation rescues these modifications (14). 


\section{THYROID HORMONE REGULATES ADULT NEUROGENESIS}

Neural stem cells in adult SGZ and SVZ slowly divide asymmetrically, giving rise to progenitors. In rodents, these highly proliferative progenitors generate neuroblasts that migrate and integrate into the pre-existing neuronal networks of the hippocampus and the olfactory bulb (OB). More recent findings highlight a third neurogenic niche within the adult rodent hypothalamus, a region regulating energy balance, food intake, and body weight $(25,26)$.

In humans, the functional role of adult neurogenesis is controversial (27-30). Both generation of new neuroblasts and their functional incorporation, especially in the $\mathrm{OB}$, is still questioned. However, recent data showed that new neurons, probably produced from the adult SVZ, are observed in the human striatum, showing that adult human SVZ can contribute to neurogenesis at least in this region (31). A decrease of neuroblasts, expressing the neuronal precursor marker doublecortin (DCX), is observed continuously from the first year after birth, in the SVZ and SGZ (29, $30,32,33)$. However, a recent study shows that a subpopulation of hippocampal neurons is able to renew, supporting the concept that adult neurogenesis occurs in humans and could contribute to cognitive functions (24).

\section{SVZ AND SGZ NICHES}

Thyroid hormone signaling is one of the main pathways vital for adult neurogenesis. Recently, $\mathrm{T}_{3}$ was demonstrated to exert critical roles in cell proliferation and NSC commitment toward neuroblasts in both the rodent SVZ and SGZ in vivo $(15,16)$. $\mathrm{T}_{3}$ acts on transcription through nuclear receptors, Thyroid Hormone Receptors (TRs). In vertebrates, different isoforms derive from the Thra (TR $\alpha 2$ and TR $\alpha 2)$ and Thrb (TR $\beta 1$ and TR $\beta 2$ ) genes. The adult hippocampus expresses TR $\alpha 1$, TR $\beta 1$, and $\beta 2$ isoforms $(16,34)$, whereas only $T R \alpha 1$ is expressed in the adult mouse $\operatorname{SVZ}(13,15)$.

$\mathrm{T}_{3}$ regulates adult neurogenesis at different steps (proliferation, survival, differentiation, and maturation). Hypothyroidism significantly reduces progenitor proliferation in the SVZ of adult mice, whereas a short $\mathrm{T}_{3}$ pulse restores mitotic activity to euthyroid levels (13). Similarly, using Ki67 as a proliferation marker and a BrdU incorporation protocol to measure cell proliferation limiting labeling of postmitotic cells, Montero-Pedrazuela et al. (14) demonstrated that hypothyroidism in adult rats, induces a decrease of proliferation (about 30\%) in the adult SGZ that is reversed by $\mathrm{T}_{4}$ treatment. Furthermore, hypothyroidism does not affect cell survival. In contrast, two others studies shown that hypothyroidism had no observable effect on numbers of proliferative progenitors in the adult SGZ progenitor proliferation but their survival was reduced, suggesting a role of $T_{3}$ on the postmitotic progenitors $(11,12)$. The reasons for these differences may reside in (i) methods for the induction of hypothyroidism (ii) and potential differences in BrdU protocols used in these studies that may or may not include postmitotic cells.

In the SGZ, TR $\alpha 1$ has different effects on proliferation and differentiation $(16,35)$. First, progenitor proliferation is unaffected by TR $\alpha 1$ loss (TR $\alpha 1^{-/-}$mutant) or overexpression (TR $\alpha 2^{-l-}$ mutant) (35). This finding correlates with the fact that TR $\alpha 1$ is not expressed in progenitors within the SGZ, but is highly expressed in post-mitotic progenitors corresponding to immature neurons (35). Second, neurogenesis is increased in TR $\alpha 1^{-/-}$mice, whereas in TR $\alpha 2^{-l-}$ mice (overexpression of TR $\alpha 1$ ), decreased survival reduces numbers of post-mitotic neuroblasts (35). These studies suggest that in the SGZ, $T_{3}$ acts at later steps than in the SVZ, in the post-mitotic progenitors $(16,35)$ (Figure 1A). Interestingly, the damaging effects of adult hypothyroidism on hippocampal neurogenesis are recapitulated in $\mathrm{TR} \alpha 2^{-I-}$ mice (35). The TR $\alpha 2^{-l-}$ mutant, in which TR $\alpha 1$ is overexpressed due to the ablation of TR $\alpha 2$, exhibit a mixed hypo- and hyperthyroid phenotype: reduced levels of $T_{4} / T_{3}$ in serum, decreased growth rate and body weight, elevated heart rate suggesting that the increased TR $\alpha 1$ levels is associated with increased receptor effects $(35,36)$. In a hypothyroid context, TR $\alpha 1$ - in this mutant - acts as an aporeceptor due to limited $\mathrm{T}_{3}$ availability. How the role of $T R \alpha 1$ aporeceptor affects adult SVZ neurogenesis is unknown. Examining this possibility should identify new TR $\alpha 1$ targets (of both liganded and unliganded receptors) involved in regulating adult neurogenesis.

In the SVZ, although TR $\alpha 1$ is absent from NSCs, it appears in proliferative Dlx2+ progenitors and is high in DCX+ neuroblasts, suggesting that TR $\alpha 1$ favors NSC commitment toward a neuronal phenotype [(15), Figure 1B]. This hypothesis is bolstered by the observation that $\mathrm{TR} \alpha 1$ gain of function in vivo generates migrating neuroblasts entering the rostral migratory stream. Inversely, shRNA-mediated TR $\alpha 1$ loss of function increases numbers of SVZ NSC/progenitors. Moreover, hypothyroidism also increases $\mathrm{NSC} /$ progenitor populations, a situation recapitulated in mutant $T R \alpha^{\circ}{ }^{\circ}$ mice (lacking all isoforms encoded by the $T R \alpha$ locus). In hypothyroidism, NSC/progenitors are blocked during interphase (13). Thus, absence of either $\mathrm{TR} \alpha 1$ or $\mathrm{T}_{3}$ induces similar effects: increasing NSC and progenitors pools, while decreasing neuroblast numbers.

In the adult SVZ, $\mathrm{T}_{3}$, through $\mathrm{TR} \alpha 1$, acts as a neurogenic switch by repressing a key gene involved in NSC pluripotency, Sox2 (15) (Figure 1B). In vivo loss and gain of TR $\alpha 1$ function approaches demonstrated that Sox2 is directly repressed by $\mathrm{T}_{3} / \mathrm{TR} \alpha 1$ in progenitors. Moreover, the progenitor to neuroblast transition - governed by $T_{3} / T R \alpha 1-$ may be reinforced by $T_{3}$ repression of CyclinD1 and $c-M y c$, involved in cell cycle progression $(13,15,37)$. Thus, $\mathrm{T}_{3}$ could regulate adult SVZ homeostasis at two levels: (i) repression of a master gene involved in NSC pluripotency and (ii) repression of cell cycle regulators.

\section{TH SIGNALING AND HYPOTHALAMIC NEUROGENESIS?}

Some authors consider that certain tanycytes (glial-like cells) in the ependymal layer are NSCs. An emerging idea is that these tanycytes are diet-responsive adult NSCs, linking food intake, body weight, and energy balance to neuronal plasticity [for reviews, see $(25,26)]$. Interestingly, $T_{3}$ is a strong regulator of energy metabolism at both peripheral and central, hypothalamic, levels (15). An exciting hypothesis is that $T_{3}$ may regulate adult hypothalamic neurogenesis and thereby modulate plasticity of hypothalamic neuronal networks regulating energy balance. Many components of TH signaling are expressed in tanycytes in the rodent brain (D2, OATP1C1, MCT8, see Figure 1C) and in turn, tanycyte activity is critical to control of the hypothalamic/pituitary/thyroid (HPT) 


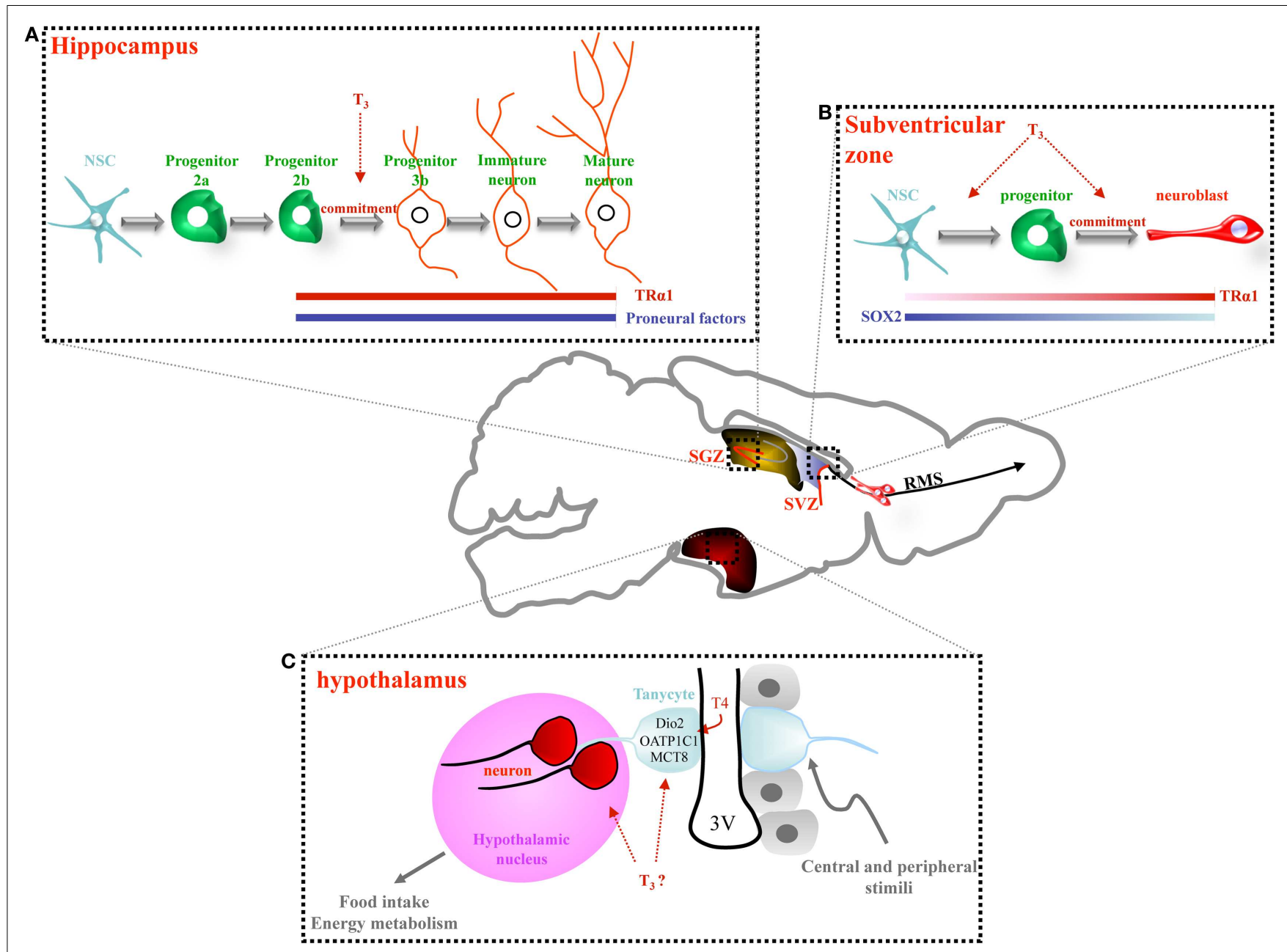

FIGURE 1 | Thyroid hormone signaling regulates adult neurogenesis in the hippocampus, the subventricular zone and, potentially, the hypothalamus. (A) In the hippocampal niche (SGZ), NSC gives rise proliferating progenitors (2a) and then, more committed progenitors (2b) and post-mitotic neuroblasts (type 3 ). Type 3 progenitors give rise to immature and mature granule neurons. A role of $T_{3}$, in concert with TR $\alpha 1$, has been observed in non-proliferating progenitors, from type $2 \mathrm{~b}$ cells to mature granule cell neurons. Adult-onset hypothyroidism or TR $\alpha 1$ overexpression (TR $\alpha 2^{-/-}$mice) alters survival of post-mitotic neuroblasts, decreasing hippocampal neurogenesis. (B) In the adult SVZ, lining the lateral ventricle, three main cell types are located: NSCs that divide asymmetrically to give rise to proliferating progenitors. Progenitors divide rapidly producing neuroblasts that migrate along the rostral migratory stream (RMS) to the olfactory bulb (OB) where they differentiate into interneurons. SOX2 and TR $\alpha 1$ are inversely expressed within the SVZ: cells expressing high levels of TR $\alpha 1$ express low levels of SOX2 (neuroblasts). $T_{3}$ is involved in both progenitor proliferation and determination. TR $\alpha 1$ overexpression in NSC and progenitors drives progenitor commitment toward a neuronal phenotype since cells overexpressing $T R \alpha 1$ are found in clusters entering the RMS. (C) In the adult hypothalamus, the third ventricle is lined by ependymal cells (in gray) interspersed with tanycytes (in blue). Some of these tanycytes are stem cells. They possess a long process that projects into hypothalamic nuclei (in pink). Some recent data support the idea that tanycytes are able to generate new neurons that migrate into adjacent hypothalamic nuclei. Tanycytes express many key actors of the TH pathway (Dio2, OATP1C1, and MCT8) thus, facilitating TH entry into the hypothalamus. These tanycytes could be considered as an "integrative platform" relaying central and peripheral signals to adapt adult neurogenesis to food intake and energy metabolism. A key role of TH in the regulation of adult hypothalamic neurogenesis is an exciting hypothesis. axis (38). How TH status and signaling affect adult hypothalamic neurogenesis in relation to feeding and energy balance is an important future research question.

\section{CONTROL OF T3 AVAILABILITY DURING ADULT NEUROGENESIS}

Some $\mathrm{T}_{3}$ effects on stem cell biology can seem paradoxical, $\mathrm{T}_{3}$ enhancing both proliferation and differentiation and exerting different actions at successive steps of neural commitment. The biological outcome of TH signaling clearly relates to cellular context, notably, chromatin state and presence of ligand, TRs, and co-factors.

One hypothesis is that adult NSCs do not integrate $\mathrm{T}_{3}$ signaling until neural determination is underway, as TR $\alpha 1$ appears in neural progenitors, with the signal increasing in neuroblasts (15). In the TR $\alpha 1$ :GFP knock-in mouse (39), expression of TR $\alpha 1$ :GFP was not investigated closely in the SVZ. Although more data is needed on the kinetics of TR expression, a critical factor will 
be $\mathrm{T}_{3}$ availability, largely determined by deiodinases. Two deiodinases are expressed in the brain, the activating deiodinase 2 (or D2, encoded by Dio2) and the inactivating deiodinase 3 (or D3, encoded by Dio3). However, there is little published data on control of TH availability during neural determination and the little available is from in vitro systems. For instance, during in vitro neuronal differentiation of a human embryonal carcinoma stem cell line (NT2 cells derived from a teratocarcinoma), TR $\alpha 1$ and TR $\beta 1$ expression is down regulated, with $\mathrm{TR} \alpha 2$ expression unchanged (40). $T_{3}$ treatment induced stronger upregulation of Dio3 in NT2 precursors than in differentiated cells.

Though hypothyroid brains show reduced NSC/precursor proliferation, no clear relationship between $\mathrm{T}_{3}$ availability and control of NSC cell cycle has yet been established. Interestingly, Dio3 expression correlates with proliferative status in solid tumors (41). This finding fits with in vitro data [from Ref. (42)] where Dio3 expression is high in early progenitors compared to human embryonic stem cells and neural progenitors. The biological significance of this finding in terms of NSC biology is hard to decipher. According to current data, local hypothyroidism favors maintenance of NSC/progenitor populations $(13,15)$ with $\mathrm{T}_{3}$ being a proliferation and neurogenic factor $(15,43)$. Similarly, expression of Dio3 within the imprinted dio3-dlk1 locus is associated with stemness (44). From an evolutionary point of view, the conservation of synteny in this locus among vertebrates seems to indicate that control of TH signaling is associated with stemness.

\section{TH CONTROL OF ADULT NEUROGENESIS IN THE AGING BRAIN}

Circulating $\mathrm{TH}$ levels decrease as a function of age in humans $(45,46)$ and rodents $(47)$. In the aging human population, both increases and decreases in circulating TSH have been observed (48-51), suggesting reduced or impaired pituitary responses in elderly people. However, higher TSH is associated with greater longevity in numerous human cohorts [see for example: (52)]. Further, neurogenesis decreases with age (53-55). THs being vital for adult neurogenesis (13), it will be interesting to address the links between these phenomena during aging.

Among the numerous genes involved in adult neurogenesis, an increase in $\mathrm{p} 16^{\text {INKA4 }}$ (CDKN2a) has been causally related to neurogenic decline during aging (56). p16 ${ }^{\mathrm{INKA} 4}$ can itself be inhibited by the synergistic action of Bmil and c-Myc $(57,58)$. Direct activation of $c-M y c$ by $\mathrm{T}_{3}$ through a TRE was shown in Xenopus intestinal stem cells (59), whereas in adult $\mathrm{SVZ} \mathrm{T}_{3}$ directly inhibits a $c-m y c$ reporter construct through an identified TRE (13). Thus, a potential indirect regulation of $\mathrm{p}^{16^{\mathrm{INKA} 4}}$ by $\mathrm{T}_{3}$ could differ according to species, cell populations and function of developmental context.

\section{DECREASING CIRCULATING THS ARE ASSOCIATED WITH COGNITIVE DECLINE AND NEURODEGENERATION}

Cognitive deficiency is frequently observed in the elderly humans and in aging rodents $(60,61)$. Marked effects are seen on learning and memory, processes that implicate neurogenesis in the dentate gyrus of the hippocampus $(62,63)$, a structure that diminishes with age and in many neurodegenerative pathologies $(62,64)$. $\mathrm{TH}$ treatment can improve cognitive performances in hypothyroid mice (8) and in humans (65), leading to speculation that cognitive deficiency can be causally linked to reduced TH signaling in aging. Despite declining neurogenesis with age, Yeung et al. recently demonstrated that 13-month-old mice still have the capacity to generate new neurons after a selective neuronal loss in the hippocampus, but without cognitive recovery (66). These results suggest that although some neurogenesis can still occur in aged mice, it might not be sufficient to compensate for neurodegeneration. TH facilitate repair after neurodegenerative lesions $(67,68)$. It is plausible that their decline is linked to decreased repair in neurodegenerative diseases of aging.

Mitochondrial biogenesis also reduces with aging (69), along with an increase in mitochondrial dysfunction (70). Thyroid signaling influences cellular metabolism and mitochondrial functions (71). Impaired thyroid signaling impacts mitochondrial respiration and hence reactive oxygen species (ROS) production, with either beneficial or damaging cellular effects (72). Since activity changes in mitochondrial respiration are linked to changes in cell proliferation rates (73), such as those occurring in the early phases of NSC differentiation, it can be postulated that mitochondrial dysfunctions impact neurogenesis, again linking reduced neurodegenerative repair capacity to decreased circulating $\mathrm{T}_{3} / \mathrm{T}_{4}$ levels. However, little is known about control of $\mathrm{T}_{4} / \mathrm{T}_{3}$ availability (deiodinase and TH transporter expression) during aging in the NSC niches, nor on the consequences of these modification for NSC metabolism, questions that it will be interesting to address.

Circadian rhythm perturbations also increase with age (74, 75). TSH (and to a lesser extent $\mathrm{T}_{3}$ ) levels display circadian rhythms (76-78), as does neurogenesis (79). Moreover, circadian clock-associated genes influence neuronal differentiation of adult NSC/progenitors (80). Two major circadian rhythm regulation genes, Bmall and Clock, are cooperatively activated by Sirt1 and $P g c 1 a$, a function that changes with age (81). In turn, SIRT1 can act as a coactivator of TR $\beta$ (82) and is implicated in neurogenesis (83). Further, Pgcla is directly regulated by $\mathrm{T}_{3}$ (84), and can itself modulate Thra expression (85). Some circadian clock-related genes are regulated by $\mathrm{T}_{3}$ (86). Thus, multiple arguments converge to suggest that impairments of circadian rhythm with age can be linked to changes in thyroid signaling, thereby impacting neurogenesis.

Induction of a chronic inflammatory state has been associated with aging $(87,88)$, and inflammation can significantly reduce neurogenesis (89-91). Brain inflammation is characterized by macrophages and microglia producing proinflammatory cytokines (TNF $\alpha$, IL-1 $\beta$, and IL-6) during prolonged inflammation. These same cytokines increase in the aging brain (92), and may enhance gliogenesis at the expense of neurogenesis (93-96). $\mathrm{TNF} \alpha$ activates the p38 MAP kinase (MAPKp38) that triggers IL$1 \beta$ production (97). As $\mathrm{T}_{3}$ can represses MAPKp38 activation by $\mathrm{TNF} \alpha$ (98), reduced $\mathrm{T}_{3}$ dependent repression of proinflammatory cytokines with aging could negatively impact neurogenesis.

\section{CONCLUSION}

Thyroid hormone is one of the few endocrine signals that exerts marked effects on both hippocampal and SVZ neurogenesis in adult mammalian brains. Although distinct differences are noted in expression of TRs and the consequences of their activation in these respective niches, it is well established that hypothyroidism 
adversely affects both populations. Given the frequency of thyroid disorders in the general population, notably in women and during aging, it is important to consider the consequences of these disorders on the incidence and severity of psychiatric and neurodegenerative disease.

\section{ACKNOWLEDGMENTS}

This work was supported by the Association Française contre les Myopathies (AFM) [grant number MNM1 2012-14685], European Union contract Switchbox [grant number FP7-Health-2010 $\mathrm{n}^{\circ} 259772$ ] and the French ANR Thrast [grant number 11BSV2 $01902]$.

\section{REFERENCES}

1. de Escobar GM, Obregón MJ, del Rey FE. Maternal thyroid hormones early in pregnancy and fetal brain development. Best Pract Res Clin Endocrinol Metab (2004) 18:225-48. doi:10.1016/j.beem.2004.03.012

2. de Escobar GM, Obregón MJ, del Rey FE. Iodine deficiency and brain development in the first half of pregnancy. Public Health Nutr (2007) 10:1554-70. doi:10.1017/S1368980007360928

3. Bernal J. Thyroid hormone receptors in brain development and function. Nat Clin Pract Endocrinol Metab (2007) 3:249-59. doi:10.1038/ncpendmet0424

4. Dugbartey AT. Neurocognitive aspects of hypothyroidism. Arch Intern Med (1998) 158:1413-8. doi:10.1001/archinte.158.13.1413

5. Fernández-Lamo I, Montero-Pedrazuela A, Delgado-García JM, GuadañoFerraz A, Gruart A. Effects of thyroid hormone replacement on associative learning and hippocampal synaptic plasticity in adult hypothyroid rats. Eur J Neurosci (2009) 30(4):679-92. doi:10.1111/j.1460-9568.2009.06862.x

6. Mirescu C, Gould E. Stress and adult neurogenesis. Hippocampus (2006) 16:233-8. doi:10.1002/hipo.20155

7. Breteler MM, van Duijn CM, Chandra V, Fratiglioni L, Graves AB, Heyman A, et al. Medical history and the risk of Alzheimer's disease: a collaborative reanalysis of case-control studies. EURODEM Risk Factors Research Group. Int J Epidemiol (1991) 20(Suppl 2):S36-42. doi:10.1093/ije/20.Supplement_2.S36

8. Fu AL, Zhou CY, Chen X. Thyroid hormone prevents cognitive deficit in a mouse model of Alzheimer's disease. Neuropharmacology (2010) 58:722-9. doi:10.1016/j.neuropharm.2009.12.020

9. Ming G-L, Song H. Adult neurogenesis in the mammalian brain: significant answers and significant questions. Neuron (2011) 70:687-702. doi:10.1016/j. neuron.2011.05.001

10. Suh H, Deng W, Gage FH. Signaling in adult neurogenesis. Annu Rev Cell Dev Biol (2009) 25:253-75. doi:10.1146/annurev.cellbio.042308.113256

11. Ambrogini P, Cuppini R, Ferri P, Mancini C, Ciaroni S, Voci A, et al. Thyroid hormones affect neurogenesis in the dentate gyrus of adult rat. Neuroendocrinology (2005) 81:244-53. doi:10.1159/000087648

12. Desouza LA, Ladiwala U, Daniel SM, Agashe S, Vaidya RA, Vaidya VA. Thyroid hormone regulates hippocampal neurogenesis in the adult rat brain. Mol Cell Neurosci (2005) 29:414-26. doi:10.1016/j.mcn.2005.03.010

13. Lemkine GF, Raj A, Alfama G, Turque N, Hassani Z, Alegria-Prévot O, et al. Adult neural stem cell cycling in vivo requires thyroid hormone and its alpha receptor. FASEB J (2005) 19:863-5. doi:10.1096/fj.04-2916fje

14. Montero-Pedrazuela A, Venero C, Lavado-Autric R, Fernández-Lamo I, GarcíaVerdugo JM, Bernal J, et al. Modulation of adult hippocampal neurogenesis by thyroid hormones: implications in depressive-like behavior. Mol Psychiatry (2006) 11:361-71. doi:10.1038/sj.mp.4001802

15. López-Juárez A, Remaud S, Hassani Z, Jolivet P, Pierre Simons J, Sontag T, et al. Thyroid hormone signaling acts as a neurogenic switch by repressing Sox2 in the adult neural stem cell niche. Cell Stem Cell (2012) 10:531-43. doi:10.1016/j.stem.2012.04.008

16. Kapoor R, Desouza LA, Nanavaty IN, Kernie SG, Vaidya VA. Thyroid hormone accelerates the differentiation of adult hippocampal progenitors. J Neuroendocrinol (2012) 24:1259-71. doi:10.1111/j.1365-2826.2012.02329.x

17. Smith JW, Evans AT, Costall B, Smythe JW. Thyroid hormones, brain function and cognition: a brief review. Neurosci Biobehav Rev (2002) 26:45-60. doi:10.1016/S0149-7634(01)00037-9

18. Joffe RT. Should thyroid replacement therapy be considered for patients with treatment-refractory depression? J Psychiatry Neurosci (2002) 27:80.
19. Henley WN, Koehnle TJ. Thyroid hormones and the treatment of depression: an examination of basic hormonal actions in the mature mammalian brain. Synapse (1997) 27:36-44. doi:10.1002/(SICI)1098-2396(199709)27: $1<36:$ AID-SYN4>3.0.CO;2-E

20. Bauer M, Heinz A, Whybrow PC. Thyroid hormones, serotonin and mood: of synergy and significance in the adult brain. Mol Psychiatry (2002) 7:140-56. doi:10.1038/sj.mp.4000963

21. Wheeler SM, McAndrews MP, Sheard ED, Rovet J. Visuospatial associative memory and hippocampal functioning in congenital hypothyroidism. J Int Neuropsychol Soc (2012) 18:49-56. doi:10.1017/S1355617711001378

22. Cooke G, Mullally S, Correia N, O'Mara S, Gibney J. Hippocampal volume is decreased in adult-onset hypothyroidism. Thyroid (2013) 24:433-40. doi:10.1089/thy.2013.0058

23. Quiñones-Hinojosa A, Sanai N, Soriano-Navarro M, Gonzalez-Perez O, Mirzadeh Z, Gil-Perotin S, et al. Cellular composition and cytoarchitecture of the adult human subventricular zone: a niche of neural stem cells. J Comp Neurol (2006) 494:415-34. doi:10.1002/cne.20798

24. Spalding KL, Bergmann O, Alkass K, Bernard S, Salehpour M, Huttner HB, et al. Dynamics of hippocampal neurogenesis in adult humans. Cell (2013) 153:1219-27. doi:10.1016/j.cell.2013.05.002

25. Bolborea M, Dale N. Hypothalamic tanycytes: potential roles in the control of feeding and energy balance. Trends Neurosci (2013) 36:91-100. doi:10.1016/j. tins.2012.12.008

26. Cheng M-F. Hypothalamic neurogenesis in the adult brain. Front Neuroendocrinol (2013) 34:167-78. doi:10.1016/j.yfrne.2013.05.001

27. Eriksson PS, Perfilieva E, Björk-Eriksson T, Alborn AM, Nordborg C, Peterson DA, et al. Neurogenesis in the adult human hippocampus. Nat Med (1998) 4(11):1313-7. doi:10.1038/3305

28. Arellano JI, Rakic P. Neuroscience: gone with the wean. Nature (2011) 478:333-4. doi:10.1038/478333a

29. Sanai N, Nguyen T, Ihrie RA, Mirzadeh Z, Tsai H-H, Wong M, et al. Corridors of migrating neurons in the human brain and their decline during infancy. Nature (2011) 478:382-6. doi:10.1038/nature10487

30. Wang X, Lui JH, Kriegstein AR. Orienting fate: spatial regulation of neurogenic divisions. Neuron (2011) 72:191-3. doi:10.1016/j.neuron.2011.10.003

31. Ernst A, Alkass K, Bernard S, Salehpour M, Perl S, Tisdale J, et al. Neurogenesis in the striatum of the adult human brain. Cell (2014) 156(5):1072-83. doi:10.1016/j.cell.2014.01.044

32. Göritz C, Frisén J. Neural stem cells and neurogenesis in the adult. Cell Stem Cell (2012) 10:657-9. doi:10.1016/j.stem.2012.04.005

33. Knoth R, Singec I, Ditter M, Pantazis G, Capetian P, Meyer RP, et al. Murine features of neurogenesis in the human hippocampus across the lifespan from 0 to 100 years. PLoS One (2010) 5:e8809. doi:10.1371/journal.pone.0008809

34. Kapoor R, Ghosh H, Nordstrom K, Vennstrom B, Vaidya VA. Loss of thyroid hormone receptor $\beta$ is associated with increased progenitor proliferation and NeuroD positive cell number in the adult hippocampus. Neurosci Lett (2011) 487:199-203. doi:10.1016/j.neulet.2010.10.022

35. Kapoor R, van Hogerlinden M, Wallis K, Ghosh H, Nordstrom K, Vennstrom B, et al. Unliganded thyroid hormone receptor alphal impairs adult hippocampal neurogenesis. FASEB J (2010) 24:4793-805. doi:10.1096/fj.10-161802

36. Saltó C, Kindblom JM, Johansson C, Wang Z, Gullberg H, Nordström K, et al. Ablation of TRalpha2 and a concomitant overexpression of Alpha1 yields a mixed hypo- and hyperthyroid phenotype in mice. Mol Endocrinol (2001) 15(12):2115-28. doi:10.1210/mend.15.12.0750

37. Hassani Z, François J-C, Alfama G, Dubois GM, Paris M, Giovannangeli C, et al. A hybrid CMV-H1 construct improves efficiency of PEI-delivered shRNA in the mouse brain. Nucleic Acids Res (2007) 35:e65. doi:10.1093/nar/gkm152

38. Fekete C, Lechan RM. Central regulation of hypothalamic-pituitary-thyroid axis under physiological and pathophysiological conditions. Endocr Rev (2013) 35:159-94. doi:10.1210/er.2013-1087

39. Wallis K, Susi D, van Hogerlinden M, Nordström K, Mittag J, Vennström B. The thyroid hormone receptor Alphal protein is expressed in embryonic postmitotic neurons and persists in most adult neurons. Mol Endocrinol (2010) 24(10):1904-16. doi:10.1210/me.2010-0175

40. Chan S, McCabe CJ, Visser TJ, Franklyn JA, Kilby MD. Thyroid hormone responsiveness in N-Tera-2 cells. J Endocrinol (2003) 178:159-67. doi:10.1677/ joe.0.1780159

41. Dentice M, Marsili A, Ambrosio R, Guardiola O, Sibilio A, Paik J-H, et al. The FoxO3/type 2 deiodinase pathway is required for normal mouse myogenesis 
and muscle regeneration. J Clin Invest (2010) 120:4021-30. doi:10.1172/ JCI43670

42. Wu JQ, Habegger L, Noisa P, Szekely A, Qiu C, Hutchison S, et al. Dynamic transcriptomes during neural differentiation of human embryonic stem cells revealed by short, long, and paired-end sequencing. Proc Natl Acad Sci U S A (2010) 107:5254-9. doi:10.1073/pnas.0914114107

43. Chen C, Zhou Z, Zhong M, Zhang Y, Li M, Zhang L, et al. Thyroid hormone promotes neuronal differentiation of embryonic neural stem cells by inhibiting STAT3 signaling through TR $\alpha 1$. Stem Cells Dev (2012) 21:2667-81. doi:10.1089/scd.2012.0023

44. Liu L, Luo G-Z, Yang W, Zhao X, Zheng Q, Lv Z, et al. Activation of the imprinted Dlk1-Dio3 region correlates with pluripotency levels of mouse stem cells. J Biol Chem (2010) 285:19483-90. doi:10.1074/jbc.M110.131995

45. Chakraborti S, Chakraborti T, Mandal M, Das S, Batabyal SK. Hypothalamicpituitary-thyroid axis status of humans during development of ageing process. Clin Chim Acta (1999) 288:137-45. doi:10.1016/S0009-8981(99)00061-3

46. Hertoghe T. The "multiple hormone deficiency" theory of aging: is human senescence caused mainly by multiple hormone deficiencies? Ann N Y Acad Sci (2005) 1057:448-65. doi:10.1196/annals.1322.035

47. Cao L, Wang F, Yang Q-G, Jiang W, Wang C, Chen Y-P, et al. Reduced thyroid hormones with increased hippocampal SNAP-25 and Munc18-1 might involve cognitive impairment during aging. Behav Brain Res (2012) 229:131-7. doi:10.1016/j.bbr.2012.01.014

48. Boucai L, Surks MI. Reference limits of serum TSH and free T4 are significantly influenced by race and age in an urban outpatient medical practice. Clin Endocrinol (Oxf) (2009) 70:788-93. doi:10.1111/j.1365-2265.2008.03390.x

49. Hadlow NC, Rothacker KM, Wardrop R, Brown SJ, Lim EM, Walsh JP. The relationship between TSH and free T4 in a large population is complex and nonlinear and differs by age and sex. J Clin Endocrinol Metab (2013) 98:2936-43. doi:10.1210/jc.2012-4223

50. Surks MI, Hollowell JG. Age-specific distribution of serum thyrotropin and antithyroid antibodies in the US population: implications for the prevalence of subclinical hypothyroidism. J Clin Endocrinol Metab (2007) 92:4575-82. doi:10.1210/jc.2007-1499

51. Peeters RP. Thyroid hormones and aging. Horm Athens Greece (2008) 7:28-35. doi:10.14310/horm.2002.1111035

52. Rozing MP, Houwing-Duistermaat JJ, Slagboom PE, Beekman M, Frölich M, de Craen AJM, et al. Familial longevity is associated with decreased thyroid function. J Clin Endocrinol Metab (2010) 95:4979-84. doi:10.1210/jc.2010-0875

53. Enwere E, Shingo T, Gregg C, Fujikawa H, Ohta S, Weiss S. Aging results in reduced epidermal growth factor receptor signaling, diminished olfactory neurogenesis, and deficits in fine olfactory discrimination. J Neurosci (2004) 24:8354-65. doi:10.1523/JNEUROSCI.2751-04.2004

54. Gould E, Reeves AJ, Fallah M, Tanapat P, Gross CG, Fuchs E. Hippocampal neurogenesis in adult Old World primates. Proc Natl Acad Sci U S A (1999) 96:5263-7. doi:10.1073/pnas.96.9.5263

55. Kuhn HG, Dickinson-Anson H, Gage FH. Neurogenesis in the dentate gyrus of the adult rat: age-related decrease of neuronal progenitor proliferation. J Neurosci (1996) 16:2027-33.

56. Molofsky AV, Slutsky SG, Joseph NM, He S, Pardal R, Krishnamurthy J, et al. Increasing p16INK4a expression decreases forebrain progenitors and neurogenesis during ageing. Nature (2006) 443:448-52. doi:10.1038/nature05091

57. Guney I, Wu S, Sedivy JM. Reduced c-Myc signaling triggers telomereindependent senescence by regulating Bmi-1 and p16(INK4a). Proc Natl Acad Sci U S A (2006) 103:3645-50. doi:10.1073/pnas.0600069103

58. Jacobs JJ, Kieboom K, Marino S, DePinho RA, van Lohuizen M. The oncogene and Polycomb-group gene bmi-1 regulates cell proliferation and senescence through the ink4a locus. Nature (1999) 397:164-8. doi:10.1038/16476

59. Fujimoto K, Matsuura K, Hu-Wang E, Lu R, Shi Y-B. Thyroid hormone activates protein arginine methyltransferase 1 expression by directly inducing $\mathrm{c}-\mathrm{Myc}$ transcription during Xenopus intestinal stem cell development. J Biol Chem (2012) 287:10039-50. doi:10.1074/jbc.M111.335661

60. Bach ME, Barad M, Son H, Zhuo M, Lu YF, Shih R, et al. Age-related defects in spatial memory are correlated with defects in the late phase of hippocampal long-term potentiation in vitro and are attenuated by drugs that enhance the cAMP signaling pathway. Proc Natl Acad Sci U S A (1999) 96:5280-5. doi:10.1073/pnas.96.9.5280

61. Cao L, Jiang W, Wang F, Yang Q-G, Wang C, Chen Y-P, et al. The reduced serum free triiodothyronine and increased dorsal hippocampal SNAP-25 and Munc18-1 had existed in middle-aged CD-1 mice with mild spatial cognitive impairment. Brain Res (2013) 1540:9-20. doi:10.1016/j.brainres. 2013.09.034

62. Gould E, Beylin A, Tanapat P, Reeves A, Shors TJ. Learning enhances adult neurogenesis in the hippocampal formation. Nat Neurosci (1999) 2:260-5. doi: $10.1038 / 6365$

63. van Praag H, Schinder AF, Christie BR, Toni N, Palmer TD, Gage FH. Functional neurogenesis in the adult hippocampus. Nature (2002) 415:1030-4. doi:10.1038/4151030a

64. Zhao C, Deng W, Gage FH. Mechanisms and functional implications of adult neurogenesis. Cell (2008) 132:645-60. doi:10.1016/j.cell.2008.01.033

65. Kramer CK, von Mühlen D, Kritz-Silverstein D, Barrett-Connor E. Treated hypothyroidism, cognitive function, and depressed mood in old age: the Rancho Bernardo Study. Eur J Endocrinol (2009) 161:917-21. doi:10.1530/EJE-090606

66. Yeung ST, Myczek K, Kang AP, Chabrier MA, Baglietto-Vargas D, Laferla FM. Impact of hippocampal neuronal ablation on neurogenesis and cognition in the aged brain. Neuroscience (2014) 259:214-22. doi:10.1016/j.neuroscience. 2013.11.054

67. Calzà L, Fernandez M, Giardino L. Cellular approaches to central nervous system remyelination stimulation: thyroid hormone to promote myelin repair via endogenous stem and precursor cells. J Mol Endocrinol (2010) 44:13-23. doi:10.1677/JME-09-0067

68. Lin H-Y, Davis FB, Luidens MK, Mousa SA, Cao JH, Zhou M, et al. Molecular basis for certain neuroprotective effects of thyroid hormone. Front Mol Neurosci (2011) 4:29. doi:10.3389/fnmol.2011.00029

69. Derbré F, Gomez-Cabrera MC, Nascimento AL, Sanchis-Gomar F, MartinezBello VE, Tresguerres JAF, et al. Age associated low mitochondrial biogenesis may be explained by lack of response of PGC- $1 \alpha$ to exercise training. Age Dordr (2012) 34:669-79. doi:10.1007/s11357-011-9264-y

70. Park CB, Larsson N-G. Mitochondrial DNA mutations in disease and aging. J Cell Biol (2011) 193:809-18. doi:10.1083/jcb.201010024

71. Weitzel JM, Iwen KA. Coordination of mitochondrial biogenesis by thyroid hormone. Mol Cell Endocrinol (2011) 342:1-7. doi:10.1016/j.mce.2011. 05.009

72. Long YC, Tan TMC, Inoue T, Tang BL. The biochemistry and cell biology of aging: metabolic regulation through mitochondrial signaling. Am J Physiol Endocrinol Metab (2014) 306:E581-91. doi:10.1152/ajpendo.00665.2013

73. Vander Heiden MG, Cantley LC, Thompson CB. Understanding the Warburg effect: the metabolic requirements of cell proliferation. Science (2009) 324:1029-33. doi:10.1126/science. 1160809

74. Campos Costa I, Nogueira Carvalho H, Fernandes L. Aging, circadian rhythms and depressive disorders: a review. Am J Neurodegener Dis (2013) 2:228-46.

75. Froy O. Circadian rhythms, aging, and life span in mammals. Physiology (Bethesda) (2011) 26:225-35. doi:10.1152/physiol.00012.2011

76. Bitman J, Kahl S, Wood DL, Lefcourt AM. Circadian and ultradian rhythms of plasma thyroid hormone concentrations in lactating dairy cows. Am J Physiol (1994) 266:R1797-803.

77. Gancedo B, Alonso-Gómez AL, de Pedro N, Delgado MJ, Alonso-Bedate M. Changes in thyroid hormone concentrations and total contents through ontogeny in three anuran species: evidence for daily cycles. Gen Comp Endocrinol (1997) 107:240-50. doi:10.1006/gcen.1997.6922

78. Morris CJ, Aeschbach D, Scheer FAJL. Circadian system, sleep and endocrinology. Mol Cell Endocrinol (2012) 349:91-104. doi:10.1016/j.mce. 2011.09.003

79. Bouchard-Cannon P, Mendoza-Viveros L, Yuen A, Kærn M, Cheng H-YM. The circadian molecular clock regulates adult hippocampal neurogenesis by controlling the timing of cell-cycle entry and exit. Cell Rep (2013) 5:961-73. doi:10.1016/j.celrep.2013.10.037

80. Kimiwada T, Sakurai M, Ohashi H, Aoki S, Tominaga T, Wada K. Clock genes regulate neurogenic transcription factors, including NeuroD1, and the neuronal differentiation of adult neural stem/progenitor cells. Neurochem Int (2009) 54:277-85. doi:10.1016/j.neuint.2008.12.005

81. Chang H-C, Guarente L. SIRT1 mediates central circadian control in the SCN by a mechanism that decays with aging. Cell (2013) 153:1448-60. doi:10.1016/j.cell.2013.05.027

82. Suh JH, Sieglaff DH, Zhang A, Xia X, Cvoro A, Winnier GE, et al. SIRT1 is a direct coactivator of thyroid hormone receptor $\beta 1$ with gene-specific actions. PLoS One (2013) 8:e70097. doi:10.1371/journal.pone.0070097 
83. Rafalski VA, Ho PP, Brett JO, Ucar D, Dugas JC, Pollina EA, et al. Expansion of oligodendrocyte progenitor cells following SIRT1 inactivation in the adult brain. Nat Cell Biol (2013) 15:614-24. doi:10.1038/ncb2735

84. Wulf A, Harneit A, Kröger M, Kebenko M, Wetzel MG, Weitzel JM. T3-mediated expression of PGC-1alpha via a far upstream located thyroid hormone response element. Mol Cell Endocrinol (2008) 287:90-5. doi:10.1016/j.mce. 2008.01.017

85. Thijssen-Timmer DC, Schiphorst MP-T, Kwakkel J, Emter R, Kralli A, Wiersinga $\mathrm{WM}$, et al. PGC-1alpha regulates the isoform mRNA ratio of the alternatively spliced thyroid hormone receptor alpha transcript. J Mol Endocrinol (2006) 37:251-7. doi:10.1677/jme.1.01914

86. Diez D, Grijota-Martinez C, Agretti P, De Marco G, Tonacchera M, Pinchera A, et al. Thyroid hormone action in the adult brain: gene expression profiling of the effects of single and multiple doses of triiodo-L-thyronine in the rat striatum. Endocrinology (2008) 149(8):3989-4000. doi:10.1210/en. 2008-0350

87. Franceschi C, Capri M, Monti D, Giunta S, Olivieri F, Sevini F, et al. Inflammaging and anti-inflammaging: a systemic perspective on aging and longevity emerged from studies in humans. Mech Ageing Dev (2007) 128:92-105. doi:10.1016/j.mad.2006.11.016

88. Strohacker K, Breslin WL, Carpenter KC, McFarlin BK. Aged mice have increased inflammatory monocyte concentration and altered expression of cell-surface functional receptors. J Biosci (2012) 37:55-62. doi:10.1007/s12038011-9169-z

89. Butovsky O, ZivY, Schwartz A, Landa G, Talpalar AE, Pluchino S, et al. Microglia activated by IL-4 or IFN-gamma differentially induce neurogenesis and oligodendrogenesis from adult stem/progenitor cells. Mol Cell Neurosci (2006) 31:149-60. doi:10.1016/j.mcn.2005.10.006

90. Ekdahl CT, Claasen J-H, Bonde S, Kokaia Z, Lindvall O. Inflammation is detrimental for neurogenesis in adult brain. Proc Natl Acad Sci U S A (2003) 100:13632-7. doi:10.1073/pnas.2234031100

91. Monje ML, Toda H, Palmer TD. Inflammatory blockade restores adult hippocampal neurogenesis. Science (2003) 302:1760-5. doi:10.1126/science. 1088417

92. Terao A, Apte-Deshpande A, Dousman L, Morairty S, Eynon BP, Kilduff TS, et al. Immune response gene expression increases in the aging murine hippocampus. J Neuroimmunol (2002) 132:99-112. doi:10.1016/S0165-5728(02) 00317-X
93. Koo JW, Duman RS. IL-1beta is an essential mediator of the antineurogenic and anhedonic effects of stress. Proc Natl Acad Sci U S A (2008) 105:751-6. doi:10.1073/pnas.0708092105

94. Lan X, Chen Q, Wang Y, Jia B, Sun L, Zheng J, et al. TNF- $\alpha$ affects human cortical neural progenitor cell differentiation through the autocrine secretion of leukemia inhibitory factor. PLoS One (2012) 7:e50783. doi:10.1371/journal. pone.0050783

95. Vallières L, Campbell IL, Gage FH, Sawchenko PE. Reduced hippocampal neurogenesis in adult transgenic mice with chronic astrocytic production of interleukin-6. J Neurosci (2002) 22:486-92.

96. Zunszain PA, Anacker C, Cattaneo A, Choudhury S, Musaelyan K, Myint $\mathrm{AM}$, et al. Interleukin-1 $\beta$ : a new regulator of the kynurenine pathway affecting human hippocampal neurogenesis. Neuropsychopharmacology (2012) 37:939-49. doi:10.1038/npp.2011.277

97. Kim SH, Smith CJ, Van Eldik LJ. Importance of MAPK pathways for microglial pro-inflammatory cytokine IL-1 beta production. Neurobiol Aging (2004) 25:431-9. doi:10.1016/S0197-4580(03)00126-X

98. Lasa M, Gil-Araujo B, Palafox M, Aranda A. Thyroid hormone antagonizes tumor necrosis factor-alpha signaling in pituitary cells through the induction of dual specificity phosphatase 1. Mol Endocrinol (2010) 24:412-22. doi:10.1210/me.2009-0298

Conflict of Interest Statement: The authors declare that the research was conducted in the absence of any commercial or financial relationships that could be construed as a potential conflict of interest.

Received: 31 January 2014; accepted: 14 April 2014; published online: 28 April 2014. Citation: Remaud S, Gothié J-D, Morvan-Dubois G and Demeneix BA (2014) Thyroid hormone signaling and adult neurogenesis in mammals. Front. Endocrinol. 5:62. doi: 10.3389/fendo.2014.00062

This article was submitted to Thyroid Endocrinology, a section of the journal Frontiers in Endocrinology.

Copyright (c) 2014 Remaud, Gothié, Morvan-Dubois and Demeneix. This is an openaccess article distributed under the terms of the Creative Commons Attribution License (CC BY). The use, distribution or reproduction in other forums is permitted, provided the original author(s) or licensor are credited and that the original publication in this journal is cited, in accordance with accepted academic practice. No use, distribution or reproduction is permitted which does not comply with these terms. 